\title{
FORMULATION AND EVALUATION OF ORODISPERSIBLE TABLETS OF GRANISETRON HYDROCHLORIDE USING PLANTAGO OVATE AS NATURAL SUPERDISINTEGRANTS
}

\author{
Chinmaya Keshari Sahoo ${ }^{1 *}$, Nalini Kanta sahoo ${ }^{2}$, Madhusmita Sahu ${ }^{2}$, \\ V. Alagarsamy ${ }^{2}$,Alok kumar Moharana ${ }^{3}$, Deepak Kumar Sarangi ${ }^{3}$, Kokkula \\ Satyanarayana ${ }^{4}$
}

\begin{abstract}
${ }^{1}$ Osmania Univ. College of Technology, Osmania University, Hyderabad, Telangana-500007,India ${ }^{2}$ MNR College of Pharmacy, Fasalwadi, Sangareddy, Medak, Telangana, 502294, India

${ }^{3}$ Omega College of Pharmacy, edulabad, ghatkesar, Ranga Reddy Dist -500388 , India 4Princeton College of Pharmacy, Princeton Group of Educational Institutions, Ghatkesar, R.R Dist. Telengana-500088,India
\end{abstract}

Submitted: 02-11-2015

Revised: $12-12-2015$

Accepted: 10-01-2016

*Corresponding author

C. Keshari Sahoo

Email:

sahoomnrcop15@gmail.com

\section{INTRODUCTION}

The advances in novel drug delivery systems for designing dosage forms like orodispersible tablets (Kuchekar et al., 2010; Chang et al., 2000) for convenient to be manufactured and administered free side effects, offering immediate release and enhance bioavailability so as to achieve better patient compliance. Oral drug delivery systems preferably tablets are most widely used dosage forms for being compact offering uniform dose and painless delivery. But elderly and pediatric patients suffer in dysphasia because of physiological changes is associated with those groups (Lindgreen and Janzon, 1993; Bhushan et al., 2000). Generally dysphasia is observed nearly $35 \%$ of population and associated with a number of conditions like parkinsonism, mental disabilities, motion sickness, unconsciousness, unavailability of water etc. To overcome such problems certain innovative drug delivery system (Sahoo et al., 2011; Chein, 1992.) like mouth dissolving tablets have been developed.

The concept of orodispersible tablets emerged from the desire to provide patient with conventional mean of taking their medication. It can be disintegrated, dissolved or suspended by saliva in the mouth resulting in easy swallowing can provide significant benefits to the pediatric and geriatric populations as well as other patients who prefer convenience of easily swallow able dosage form. Orodispersible tablets disintegrate instantaneously when placed on tongue, releasing the drug that dissolves or disperses in the saliva. The orally disintegrating tablets are also called as orodispersible tablets, quick disintegrating tablets, fast disintegrating 
tablets, porous tablets, rapimelts. The mouth dissolving tablets are absorbed from the mouth, pharynx and esophagus as saliva passes down into the stomach (Sahoo et al, 2013). The solution containing active ingredients is absorbed through gastrointestinal epithelium to reach the target and produce desired effect. In these cases the bioavailability of drugs are significantly greater than those observed from conventional solid dosage forms such as tablets and capsules (Wilson et al., 1987).

Granisetron hydrochloride is a selective 5-HT3 receptor antagonist which has effect on controlling nausea and vomiting. Its main effect is to reduce the activity of the vagus nerve which is a nerve that activates the vomiting centre in medulla oblongata. During chemotherapy induced vomiting, mucosal enterochromaffin cells release serotonin which stimulates 5-HT3 receptors. The stimulation of 5-HT3 receptors by serotonin causes vagal discharge resulting in vomiting. Granisetron blocks serotonin stimulation and is more effective than ondansetron when used in combination with dexamethasone in the prevention of acute and delayed vomiting caused by high emetogenic chemotherapy. Granisetron hydrochloride undergoes hepatic first pass metabolism with a bioavailability of $60 \%$ and terminal elimination half life between 3 to $14 \mathrm{~h}$ after oral administration (Patil et al., 2011). In the present study orodispersible tablets of granisetron hydrochloride were designed using wet granulation method using various excipients and plantago ovate as natural super disintegrants with prime objective arriving of a cost effective product (Bhaskran and Narmada, 2002).

\section{MATERIAL AND METHODS}

Granisetron hydrochloride was received as a gift sample from Suzikem Labs Pvt Ltd., cherlapally, A.P, Mannitol and Aerosil were obtained as gifts from Aurobindo labs Pvt Ltd, A.P. sodium saccharin, magnesium stearate, talc, micro crystalline cellulose,and potassium dihydrogen-o-phosphate were procured from SD fine chem. Ltd Mumbai. Sodium hydroxide, sodium lauryl sulphate and methanol were procured from Qualigens fine chemicals Mumbai.

\section{Drug excipient studies}

The FTIR spctroscopy allows identification of functional groups in various chemicals as well as incompatibilities between the drug and excipients. From the FTIR spectroscopy study it can be concluded that the major peaks of drug remains intact and no interaction was found between the drug and excipients.

\section{Preparation of orodispersible tablets}

Accurately weighed quantities of ingredients mentioned in table I were passed through sieve no. 12. and plantego ovate was passed through sieve no.20. All the ingredients lubricant magnesium stearate and talc (glidant) were manually blended homogenous by way of geometric dilution. The mixture was moistened with aqueous solution and granulated with sieve no.20 and placed in hot air oven at $50^{\circ} \mathrm{C}$ for sufficient 3-4h. Then dried granules passed through sieve no.12 and blended with magnesium stearate and talc. The homogenous mixture were placed into tablet punching machine (10 station rotary tablet machine Clint India) getting tablet weight $190 \mathrm{mg}$ each using deep concave punch.

\section{Evaluation of granules}

Pre compression parameters of orodispersible tablets

\section{Angle of repose}

The angle of repose (Aithal et al., 2006.) of granules blend was determined by the fixed funnel method. The accurately weighed quantity of granules was taken in a funnel. The height of funnel was adjusted in such a way that the tip of the funnel just touched the apex of the heap of the granules. The granules are allowed to flow through the funnel freely onto the surface. The diameter of powder cone was measured and angle of repose was calculated using the following equation

$$
\begin{array}{ll}
\tan \Theta & =\mathrm{h} / \mathrm{r} \\
\Theta & =\tan ^{-1}(\mathrm{~h} / \mathrm{r})
\end{array}
$$

Where $\Theta$ is the angle of repose, h is the height of cone in $\mathrm{cm}$ and $\mathrm{r}$ is the radius of the cone base in $\mathrm{cm}$. 


\section{Bulk density $\left(e_{b}\right)$}

Bulk density was determined by pouring the granules into a graduated cylinder. The bulk volume $\left(\mathrm{V}_{\mathrm{b}}\right)$ and mass $(\mathrm{m})$ of the granules was determined. The bulk density was calculated (Sahoo et al., 2015)by using the following formula.

Bulk density Mass of granules $(\mathrm{m})$

$$
\left(\mathrm{e}_{\mathrm{b}}\right)=\text { Bulk volume of granules }\left(\mathrm{V}_{\mathrm{b}}\right)
$$

\section{Tapped density $\left(e_{t}\right)$}

The measuring cylinder containing known mass of granules blend was tapped 1000 times for a fixed time. The minimum volume occupied in the cylinder $\left(\mathrm{V}_{\mathrm{t}}\right)$ and mass of the granules (m) was measured. The tapped density was measured (Satyanarayana et al., 2015) by using the following formula.

Tapped Mass of granules(m) density $\left(\mathrm{e}_{\mathrm{b}}\right)=$ Tapped volume of granules $\left(\mathrm{V}_{\mathrm{b}}\right)$ density $\left(e_{t}\right)=$ Mass of granules $(m) /$ Tapped volume of granules $\left(V_{b}\right)$

\section{Compressibility index (Carr's index)}

The compressibility index (Danagi et al., 2006.) [14] determines the flow property characteristics of granules developed by Carr. The percentage compressibility of granules is a direct measure of the potential powder arch and stability. The Carr's index can be calculated by the following formula.

$\%$ Carr's index $=\frac{e_{t}-e_{b}}{e_{t}} \times 100$

Where $e_{t}$ is the tapped density of granules and $e_{b}$ is bulk density of granules

\section{Hausner's ratio}

Hausner's ratio is used for the determination of flow properties of granules (Sahoo et al., 2015). The ratio can be calculated by the taking the ratio of tapped density to the ratio of bulk density.

\section{Post compression orodispersible tablets Thickness}

parameters of

The thickness of individual tablets is measured by using vernier calliper (Sahoo et al., 2012) which gives the accurate measurement of thickness. It provides information of variation of thickness between tablets. Generally the unit for thickness measurement is $\mathrm{mm}$. The limit of the thickness deviation of each tablet is $\pm 5 \%$.

\section{Hardness}

The hardness of prepared tablets was determined by using Monsanto hardness tester (Shishu et al., 2007) and measured in terms of $\mathrm{kg} / \mathrm{cm}^{2}$. Test was done in triplicate.

\section{Friability}

Friability (Malke et al., 2007) of tablets was performed in a Roche friabilator. Ten tablets were initially weighed $\left(\mathrm{W}_{0}\right)$ together and then placed in the chamber. The friabilator was operated for 100 revolutions and the tablets were subjected to the combined effects of abrasion and shock because the Plastic chamber carrying the tablets drops them at a distance of six inches with every revolution. The tablets are then dusted and reweighed (W). The percentage of friability was calculated using the following equation.

$\%$ Friability $=\mathrm{F}=\left(1-\frac{\mathrm{W}_{0}}{\mathrm{~W}}\right) \times 100$

Where, $\mathrm{W}_{0}$ and $\mathrm{W}$ are the weight of the tablets before and after the test respectively. The limit for percentage of friability is between $0.5-1 \%$.

\section{Weight variation}

The weight variation test [19] was done by weighing 20 tablets individually (Shimadzu digital balance), calculating the average weight and comparing the individual tablet weights to the average. The percentage weight deviation was calculated and then compared with USP specifications.

\section{Disintegration test}

Six tablets along disc were introduced in each tube of basket of disintegration (Jain et al., 2009) test apparatus (Lab care instruments). The basket was positioned into a beaker containing $900 \mathrm{~mL}$ of distilled water and operated at $37 \pm 2^{\circ} \mathrm{C}$. The time of disintegration of tablet was recorded. The average time and standard deviation were calculated. Three trails were performed. 


\section{Wetting time}

The Wetting time (Bhardwaj et al., 2010) of the tablets can be measured using a simple procedure. Five circular tissue papers of $10 \mathrm{~cm}$ diameter are placed in petri dish with a $10 \mathrm{~cm}$ diameter. Wetting time was measured by placing a tablet on a piece of tissue paper folded twice, and was placed in a small petri dish containing $6 \mathrm{~mL}$ of simulated saliva $\mathrm{pH} 6.8$, and the time for complete wetting was measured. Five tablets from each batch were used.

\section{Water absorption ratio:}

A piece of tissue paper folded twice was placed in a small Petri dish (internal diameter = $6.5 \mathrm{~cm}$ ) containing $5 \mathrm{~mL}$ of distilled water. A tablet was placed on the tissue paper. The wetted tablet was weighed. The test was done in triplicate. The water absorption (Swamy et al., 2007) ratio(R) was determined according to the following equation,

Water absorption $=\frac{\mathrm{Wa}-\mathrm{W}_{\mathrm{b}}}{\mathrm{W}_{\mathrm{a}}} \times 100$

Where, $W_{a}$ is the weight of the tablets before the test and $\mathrm{W}_{\mathrm{b}}$ is the weight of the tablet after water absorption.

\section{Drug content}

Drug content for ORD tablet was done by the assay method (Bi et al., 1999; Bhagwati et al., 2005). First the prepared tablet (2mg API) was crushed and added to $10 \mathrm{~mL}$ of phosphate buffer $\mathrm{pH}$ 6.8. After $30 \mathrm{~min}$ the solution was filtered and from $10 \mathrm{~mL}$ solution $1 \mathrm{~mL}$ solution was withdrawn diluted upto $20 \mathrm{~mL}$ with phosphate buffer $\mathrm{pH} \quad 6.8(10 \mu \mathrm{g} / \mathrm{mL})$. This solution concentration for the drug content of formulations were calculated using calibrated standard curve equation $y=0.033 x+0.018$. The drug content was determined at $\lambda \max 302 \mathrm{~nm}$ by UV-spectrophotometer (ELICO164) against blank.

\section{In vitro dissolution studies}

The release rate of Granisetron hydrochloride (Aithal et al., 2006; Desai et al., 2006). Orodispersible tablets was determined using United States pharmacopeia (USP) dissolution testing apparatus type 2 (paddle method). The dissolution test was performed using $900 \mathrm{~mL}$ of Phosphate buffer $\mathrm{pH}$ 6.8, at $37^{\circ} \pm 0.5^{\circ} \mathrm{C}$ and $50 \mathrm{rpm}$. In specified time intervals $(0,0.5,1,1.5,2,2.5,3,3.5,4,4.5 \mathrm{~min})$ an aliquot of $5 \mathrm{~mL}$ samples of the solution were withdrawn from the dissolution apparatus and with replacement of fresh fluid to dissolution medium. The samples were filtered through filter paper of $0.45 \mu \mathrm{m}$. Absorbance of these solutions were measured at $\lambda \max 302 \mathrm{~nm}$ using a UV/Visible Spectrophotometer (ELICO164). The drug release was plotted against time to determine the release profile of various batches.

\section{In vitro dispersion time}

This test is performed to ensure disintegration of tablets in the salivary fluid, if it is to be used as an orodispersible tablet. In vitro dispersion (Chaudhari et al., 2005) time was measured by dropping a tablet in a measuring cylinder containing $6 \mathrm{~mL}$ of simulated salivary fluid of $\mathrm{pH}$ 6.8. Three tablets from each formulation were randomly selected and in vitro dispersion time was measured.

\section{Stability studies}

Tablets were stored at $40 \pm 2^{\circ} \mathrm{C} / 75 \pm 5 \%$

$\mathrm{RH}$ for a storage period of 0 days, 30 days, 60 days and 90 days for short term stability study (Patil et al., 2011). The post compression parameters of tablets were tested during the storage period. The changes of dissolution and drug content were compared for stability study.

\section{RESULTS AND DISCUSSION Drug excipient studies}

The FTIR spectroscopy allows identification of functional groups in various chemicals as well as incompatibilities between the drug and excipients. From the FTIR spectroscopy study it was found that there was no interaction between peaks of drug as well as other ingredients. So from the study it can be concluded that the major peaks of drug remains intact and no interaction was found between the drug and disintgrants. Hence drug and excipients are compatible to each other.

\section{Pre-compression parameters of ORD formulations}

All the compressible excipients (Table I) with drug by wet granulation method was 
Table I. Composition of granisetron hydrochloride orodispersible tablets containing natural superdisintegrants

\begin{tabular}{lrrrrrr}
\hline Ingredients(mg) & F1 & F 2 & F 3 & F 4 & F 5 & F 6 \\
\hline GSH & 2 & 2 & 2 & 2 & 2 & 2 \\
Plantago Ovate & 4 & 6 & 8 & 10 & 12 & 14 \\
Micro Crystalline Cellulose & 126 & 124 & 122 & 120 & 118 & 116 \\
Mannitol & 50 & 50 & 50 & 50 & 50 & 50 \\
Aerosil & 2 & 2 & 2 & 2 & 2 & 2 \\
Sodium Saccharin & 2 & 2 & 2 & 2 & 2 & 2 \\
Magnesium Stearate & 2 & 2 & 2 & 2 & 2 & 2 \\
Talc & 2 & 2 & 2 & 2 & 2 & 2 \\
Total weight $(\mathrm{mg})$ & 190 & 190 & 190 & 190 & 190 & 190 \\
\hline
\end{tabular}

Where $\Theta$ is the angle of repose, $h$ is the height of cone in $\mathrm{cm}$ and $\mathrm{r}$ is the radius of the cone base in $\mathrm{cm}$.

Table II. Relationship between powder flowability and angle of repose

\begin{tabular}{cc}
\hline Angle of repose $(\boldsymbol{\theta})$ & Observation \\
\hline$<25^{0}$ & Free flowing granules \\
$>40^{\circ}$ & Poorly flowing granules \\
\hline
\end{tabular}

Table III. Relationship between powder flowability and \% compressibility range

\begin{tabular}{ll}
\hline \%Compressibility index & Flow type \\
\hline $5-15$ & Excellent flow(free flowing granules) \\
$12-16$ & Good \\
$18-21$ & Fair(powdered granules) \\
$23-28$ & Poor(very fluidpowders) \\
$28-35$ & Poor(fluid cohesive powders) \\
$35-38$ & Very poor(fluid cohesive powders) \\
$>40$ & Extremely poor(cohesive powders) \\
\hline
\end{tabular}

prepared using Plantago Ovate along with magnesium stearate and talc. This granules were evaluated for pre-compressionparameters (Table V) such as bulk density, tapped density, angle of repose and Carr's index.

The bulk density of pre-compression blends was found to be in the range of 0.52 to $0.68 \mathrm{~g} / \mathrm{mL}$, tapped density in the range of 0.56 to $0.74 \mathrm{~g} / \mathrm{mL}$, the Carr's index values were in the range of 12 to $20 \%$, angle of repose in the ranges from 23 to 29 degrees and the hausner's ratio was in the range between 1.07 to 1.17 .

\section{Post-compression parameters of ORD formulations}

The post compression parameters such as hardness, weight variation, drug content uniformity, friability and thickness have given below (Table VI). The other parameters such as wetting time, disintegration time and in vitro dispersion time have given below (Table VII).

The hardness of the tablet formulations was found to be in the range of $3.85 \mathrm{to} 3.94 \mathrm{~kg} / \mathrm{cm}^{2}$. The friability values were found to be in the range of 0.49 to $0.57 \%$. The weight of all the tablets was found to be uniform with low values of standard deviation and within the prescribed USP limits. The average weight of one tablet was found to be in range 189 to $190 \mathrm{mg}$. The percent drug content of all the tablets was found to be in the range of 99.1 to $99.9 \%$ of the expected drug content, which was within the acceptable limits.

The disintegration time was in range 17 to $27 \mathrm{~s}$, wetting time was found be in range 14 
Formulation and Evaluation of Orodispersible

Table IV. Relationship betw een powder flow ability and Hausner's ratio

\begin{tabular}{ll}
\hline Hausner's ratio & Flow type \\
\hline 1.2 & Free flowing granules \\
$>1.6$ & Poorly flowing granules \\
\hline
\end{tabular}

Table V. Pre-compression parameters of ORD formulations

\begin{tabular}{ccccrr}
\hline $\begin{array}{c}\text { Formulation } \\
\text { code }\end{array}$ & $\begin{array}{c}\text { Bulk density } \\
(\mathbf{g m} / \mathbf{m L}) \pm \text { S.D }\end{array}$ & $\begin{array}{c}\text { Tapped density } \\
(\mathbf{g m} / \mathrm{mL}) \pm \text { S.D }\end{array}$ & $\begin{array}{c}\text { Angle of repo se Carr's index } \\
\text { (degree) } \pm \text { S.D }\end{array}$ & $\begin{array}{c}\text { Hausner's } \\
\text { (\%) } \pm \text { S.D }\end{array}$ & Ratio \pm S.D \\
\hline F1 & $0.56 \pm 0.02$ & $0.66 \pm 0.08$ & $23.0 \pm 0.03$ & $15.15 \pm 0.02$ & $1.17 \pm 0.08$ \\
F2 & $0.68 \pm 0.11$ & $0.74 \pm 0.09$ & $25.0 \pm 0.12$ & $8.1 \pm 0.13$ & $1.08 \pm 0.12$ \\
F3 & $0.54 \pm 0.13$ & $0.68 \pm 0.11$ & $24.0 \pm 0.11$ & $20.58 \pm 0.01$ & $1.2 \pm 0.125$ \\
F4 & $0.58 \pm 0.14$ & $0.66 \pm 0.02$ & $26.0 \pm 0.13$ & $12.12 \pm 0.01$ & $1.13 \pm 0.01$ \\
F5 & $0.52 \pm 0.15$ & $0.56 \pm 0.02$ & $27.0 \pm 0.01$ & $7.1 \pm 0.14$ & $1.07 \pm 0.09$ \\
F6 & $0.53 \pm 0.11$ & $0.58 \pm 0.14$ & $29.0 \pm 0.09$ & $8.62 \pm 0.11$ & $1.09 \pm 0.11$ \\
\hline
\end{tabular}

Table VI. Post-compression parameters of ORD formulations

\begin{tabular}{cccccc}
\hline $\begin{array}{c}\text { Formulation } \\
\text { code }\end{array}$ & $\begin{array}{c}\text { Hardness } \\
\left(\mathbf{k g} / \mathbf{c m}^{2}\right) \mathbf{\pm S . D}\end{array}$ & $\begin{array}{c}\text { Friability } \\
\mathbf{( \% )} \pm \text { S.D }\end{array}$ & $\begin{array}{c}\text { \%Drug } \\
\text { Content } \pm \text { S.D }\end{array}$ & $\begin{array}{c}\text { Average wt. of } \\
\text { 1tablet(mg) } \pm \text { S.D }\end{array}$ & $\begin{array}{c}\text { Thickness } \\
(\mathbf{m m}) \pm \text { S.D }\end{array}$ \\
\hline F1 & $3.9 \pm 0.02$ & $0.49 \pm 0.11$ & $99.2 \pm 0.01$ & $191 \pm 0.1$ & $4 \pm 0.10$ \\
F2 & $3.89 \pm 0.01$ & $0.52 \pm 0.01$ & $99.4 \pm 0.02$ & $190 \pm 0.1$ & $4 \pm 0.11$ \\
F3 & $3.85 \pm 0.02$ & $0.57 \pm 0.02$ & $99.3 \pm 0.03$ & $190 \pm 0.1$ & $4 \pm 0.14$ \\
F4 & $3.94 \pm 0.05$ & $0.51 \pm 0.10$ & $99.9 \pm 0.04$ & $189 \pm 0.1$ & $4 \pm 0.13$ \\
F5 & $3.85 \pm 0.01$ & $0.52 \pm 0.01$ & $99.4 \pm 0.02$ & $190 \pm 0.1$ & $4 \pm 0.10$ \\
F6 & $3.85 \pm 0.02$ & $0.53 \pm 0.04$ & $99.1 \pm 0.02$ & $189 \pm 0.1$ & $4 \pm 0.10$ \\
\hline
\end{tabular}

Table VII. Post-compression parameters of ORD formulations

\begin{tabular}{|c|c|c|c|c|}
\hline $\begin{array}{c}\text { Formulation } \\
\text { code }\end{array}$ & $\begin{array}{c}\text { Disintegration } \\
\text { time(s) } \pm \text { S.D }\end{array}$ & $\begin{array}{c}\text { In vitro dispersion } \\
\text { time(s) } \pm \text { S.D }\end{array}$ & $\begin{array}{c}\text { Wetting } \\
\text { time }(\mathrm{sec}) \pm \text { S.D }\end{array}$ & $\begin{array}{c}\text { Water absorption } \\
\text { ratio } \pm \text { S.D }\end{array}$ \\
\hline F1 & $27 \pm 1.01$ & $34 \pm 1.02$ & $24 \pm 1.1$ & $68.23 \pm 1.3$ \\
\hline F2 & $24 \pm 1.05$ & $30 \pm 1.02$ & $20 \pm 1.02$ & $71.50 \pm 1.8$ \\
\hline F3 & $22 \pm 1.11$ & $26 \pm 1.02$ & $17 \pm 1.06$ & $78.51 \pm 1.2$ \\
\hline F4 & $17 \pm 1.23$ & $20 \pm 1.02$ & $14 \pm 1.07$ & $80.48 \pm 1.6$ \\
\hline F5 & $19 \pm 1.12$ & $27 \pm 1.01$ & $22 \pm 1.02$ & $72.50 \pm 1.8$ \\
\hline F6 & $24 \pm 1.04$ & $30 \pm 1.02$ & $19 \pm 1.02$ & $66.23 \pm 1.3$ \\
\hline
\end{tabular}

to $24 \mathrm{~s}$, in vitro dispersion time was in range 20 to $34 \mathrm{~s}$ and the water absorption ratio was between 66.23 to 80.48 . The results are shown in table VII.

\section{In vitro dispersion time}

This test was performed to ensure disintegration of tablets in the salivary fluid, if it is to be used as an orodispersible tablet. Among all formulations F4 formulation was found to be best. The dispersion time was found to be 20s (Figure 1).

\section{In vitro drug release study}

In vitro drug release studies were performed in $\mathrm{pH} 6.8$ phosphate buffer, on the above promising formulation (F4) gives maximum amount of drug release comparing to other formulations. The percentage of drug release of $\mathrm{F} 4$ was best giving $99.11 \%$ in $3 \mathrm{~min}$ comparing to other batches F1 (93.92\% in $4.5 \mathrm{~min}), \quad \mathrm{F} 2$ (95.43 in $4 \mathrm{~min}), \mathrm{F} 3$ (97.32in $3.5 \mathrm{~min}), \mathrm{F} 5$ (96.23 in $4.5 \mathrm{~min}$ ) and F6 (95.26 in $4.5 \mathrm{~min})$. The dissolution profiles of the above formulations are depicted in figure 2. 


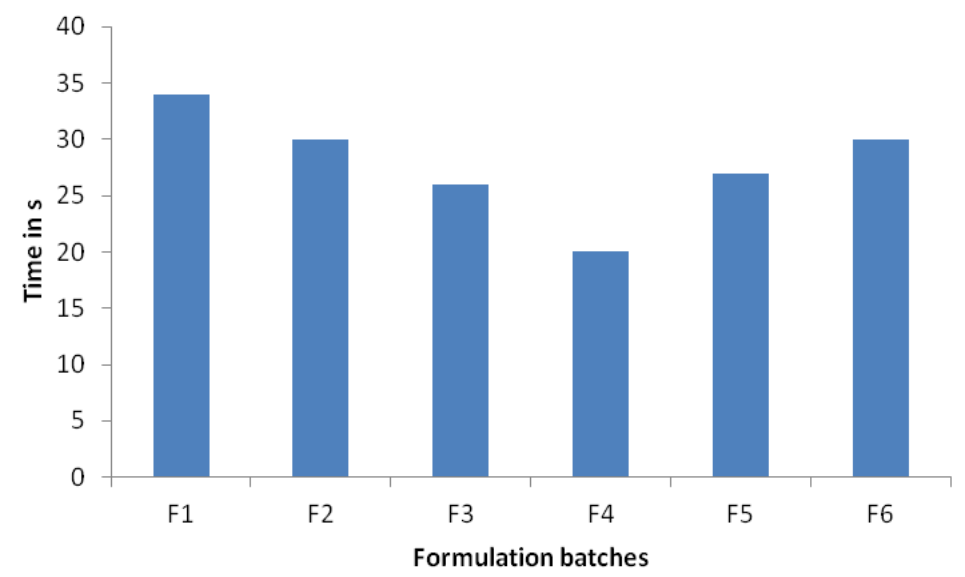

Figure 1. In vitro dispersion time of orodispersible tablets

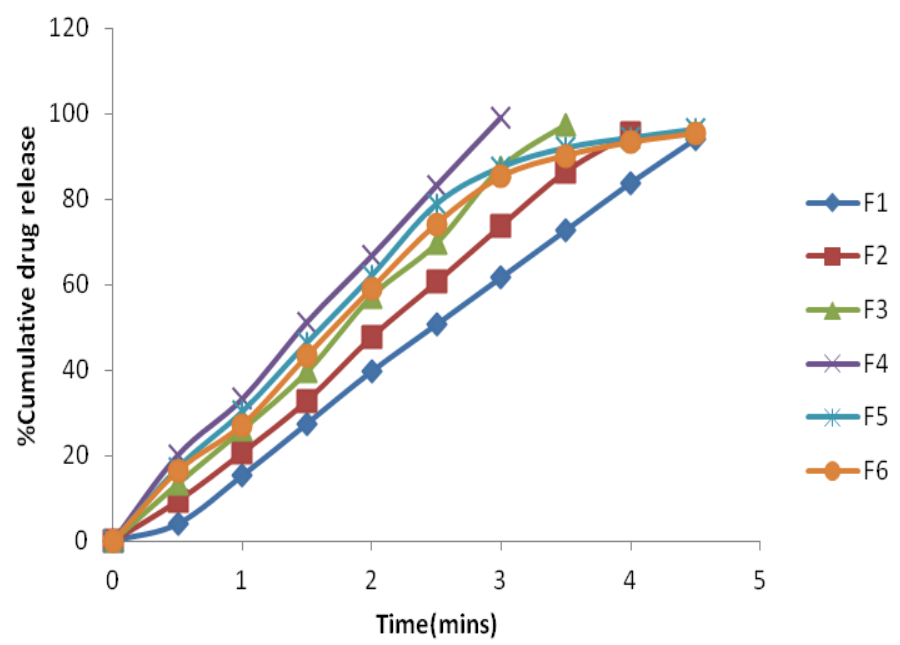

Figure 2. Comparative in vitro drug release study of GSH batches.

\section{Short-term sta bility studies}

Short-term stability studies on the above promising formulation (at $40 \pm 2 \% / 75 \pm 5 \% \mathrm{RH}$ for 3 months) have shown no significant changes in physical appearance, drug content and in vitro dispersion time. Statistical analysis ('t'-test) of drug content data gives ' $t$ ' value of 1.91 for F4 formulation which is much less compared to the table value of $4.3(\mathrm{p}<0.05)$. There are no appreciable changes in in vitro dispersion time up on storage at $40 \pm 2 \circ / 75 \pm 5 \%$ RH for 3 months period.

\section{CONCLUSION}

The study clearly demonstrates that orodispersible tablets of granisetron hydrochloride could be successfully prepared by wet granulation method in a cost effective manner employing plantego ovate. It was evident from the results that rate of drug release can be optimized using disintegrants for orodispersible formulations. From the developed formulations the release of granisetron hydrochloride was best in F4 formulation i.e in-vitro study and in vitro dispersion time study. From the FTIR spectroscopy study, it was confirmed that the drug and excipients in the formulations were compatible with each other. Hence the availability of various technologies and the manifold advantages of orodispersible tablets will surely enhance the patient compliance providing rapid onset of action. 


\section{ACKNOWLEDGEMENT}

The authors are acknowledged Osmania University supporting this research

\section{REFE RE NCES}

Aithal K., Harish N., Rathnanand M., Shirwaikar M., Shirwaikar A., 2006. Once daily fast dissolving tablets granisetron hydrochloride formulation and in vitro evaluation. Ind.Drg. 43(7): 576-580.

Bhagwati ST., Hiremath SN., Sreenivas SA., 2005. Comparative evaluation of disintegrants by formulating cefixime dispersible tablets. Ind. J. Pharm. Edu. Res. 39: 194-197.

Bhardwaj V., Bansal M., Sharma PK., 2010. Formulation and evaluation of fast dissolving tablets of amlodipine besylate using different super disintegrants and camphor as sublimating agents. AmericanEur. J. of Scientific Research. 5(4):264-269.

Bhaskran S., Narmada GV., 2002. Rapid dissolving tablet: A Novel dosage form. Ind. Pharmac. 1:9-12.

Bhushan YS., Sambhaji PS., Anant PR., Kakashaheb M. R., 2000. New drug delivery system for elderly. Ind. Dr. 373:12-318.

Bi YX., Sunada H. Yonezawa Y. Danjo K., 1999. Evaluation of rapidly disintegrating tablets by direct compression method. Drg. Dev. Ind. Pharm. 25: 571-81.

Chang R. Guo X. Burnside BA., Couch RA., 2000. A Review of fast dissolving tablets. Pharm. Tech. 24(6): 52-58.

Chaudhari PD., Chaudhari SP., Kohle SR., Dave KV., More DM., 2005. Formulation and evaluation of fast dissolving tablets of famotidine. Ind. Drg. 42: 641-649.

Chein YW., 1992. Oral drug and delivery systems, 2nded New York; Marcel Dekker.

Danagi PM., Halakatti PK., Mastiholimath V. M., Patil MB., Manvi F. V., 2006. Rapidly disintegrating domperidone tablets. Ind. Drg. 43(7): 594-597.

Desai SA., Kharade SV., Petkar KC., Kuchekar BS., 2006. Orodissolving tablets of promethazine hydrochloride.Ind.J. Pharm. Edu. Res. 40(6): 172-174.
Jain CP., Naruka PS., 2009. Formulation and evaluation of fast dissolving tablets of valsartan. Int. Pharm. Pharmacentical $\operatorname{Scie1}(1): 219-226$.

Kuchekar BS., Bhise SB., Arungam V., 2010. Design of fast dissolving tablets. Ind. J. Pharm. Edu. 35: 150.

Lindgreen S., Janzon L., 1993. Dysphagia: prevalence of swallowing complaints and clinical findings.Med. Clin.North. Am. 77:3-5.

Malke S., Shidaye S., Kadam VJ., 2007. Formulation and evaluation of oxcarbazepine fast dissolve tablets. Ind.J Pharm Sci. 69(2): 211-214.

Patil BS., Rao DK., Kulkarni U., Harriprasanna RC., Gada M. M., 2011. Formulation and evaluation fast dissolving tablets of granisetron hydrochloride by direct compression technique. Int. J. Curr. Pharma. Res. 3(2): 124-128.

Patil BS., Rao KD., Kulkarni U., 2011. Formulation and development of granisetron hydrochloride fast dissolving tablets by sublingual technique. Int. J. Pharm. Pharma.Sci. Res. 1(1): 20-25.

Sahoo CK., Rao SRM., Sudhakar M., 2015. Evaluation of controlled porosity osmotic pump tablets:a review. Research J.Pharm and Tech.8(12):119-125.

Sahoo CK., Rao SRM., Sudhakar M., Satyanarayana K., Sahoo NK.,2015. A review on controlled porosity osmotic pump tablets and its evaluation. Bull.Fac.Pharm., Cairo Univ. 53(2): 195-205.

Sahoo CK., Reddy AA., Kethavath V., Surabi P., Mule E., 2013. Designing of orodispersible tablet of metformin hydrochloride for the treatment of type II diabetes mellitus. World J. Pharm. Res. 2(6): 3156-3164.

Sahoo CK., Sahoo TK., Moharana AK., Panda KC., 2012. Formulation and optimization of porous osmotic pump based controlled release system of residronate sodium for the treatment of postmenopausal osteoporosis. Int.J.Pharm ScieRevRes. 12(1):118-122.

Sahoo CK., Sahoo TK., Moharana AK., 2011. Designing of orodispersible tablet of diethyl carbamazine citrate for the 
treatment of filariasis. Int.J. Appl. Biol. Pharm. Tech. 2(4): 70-74.

Sahoo CK., Satyanarayana K., Bhargavi G., Sahoo NK., 2015. Formulation and evaluation of olanzapine sustained release matrix tablets for the treatment of schizophrenia.Der Pharmacia Sinica.6(5) $: 15-21$.

Satyanarayana K., Sahoo CK., Bhargavi G., Sahoo NK., 2015. Formulation and optimization of olanzapine sustained release matrix tablets for the treatment of schizophrenia. Der Pharmacia Lettre. 7(4):266-273.
Shishu, Bhatti A., Singh T., 2007. Preparation of tablets rapidly disintegrating in saliva containing bitter taste masked by compression method. Ind.J Pharm Sci. 69(1): 80-84.

Swamy PV., Areefulla SH., Shirsand SB., Gandra S, Prashanth B., 2007. Orodispersible tablets of meloxicam using disintegrant blends for improved efficacy.Ind.J Pharm Sci. 69(6): 836-40.

Wilson GC., Washington N., Peach J., Murray RG., Kennerley J., 1987. The behavior of a fast-dissolving dosage form (Expidet) followed by g-scintigraphy. Int.J.Pharm. 40:119-123. 